Cite: Pozniak, O. V. (2021). Ukrainian Migrants in Europe: Situation Depending on the Region of Stay. Demography and Social Economy, 2 (44), 110-126. https://doi.org/10.15407/dse2021.02.110

https://doi.org/10.15407/dse2021.02.110

УДК 331.556 .4 (477)

JEL CLASSIFICATION: J61

O. V. POZNIAK, PhD (Economics), Head of sector

Ptoukha Institute for Demography and Social Studies

of the National Academy of Sciences of Ukraine

01032, Kyiv, Blvd Tarasa Shevchenko, 60

E-mail: olex_poznyak@ukr.net

ORCID 0000-0002-1323-3896

Scopus ID 57195780028; 57189273845

\title{
UKRAINIAN MIGRANTS IN EUROPE: SITUATION DEPENDING ON THE REGION OF STAY
}

Ukraine has become one of the largest donors of population and labor force in Europe. The assessment of the migration of Ukrainians to the countries of Europe is based on data from three national surveys on external labor migration (2008, 2012,2017), a survey in the framework of the TEMPER project with the participation of the author (2017-2018), as well as data from a number of studies of Ukrainian labor migration conducted in Ukraine and in recipient countries. The purpose of the paper is a comparative analysis of the migration of Ukrainians to different regions of Europe. Methods of the research are system approach, method of complex use of information from different sources, comparative and graphic methods. Scientific novelty of the paper is to identify the features of external labor migration of citizens of Ukraine depending on the geographical direction of movement. The changes in the trends of external labor migration of Ukrainians that occurred since the independence are analyzed. A comparative analysis of the migration of Ukrainians to Western and Eastern Europe was carried out. It is shown that labor trips to countries neighboring Ukraine mostly remain circular and short-term. Migration to Western Europe is characterized by a transition from circular to permanent migration, with the formation of new Ukrainian Diasporas in the recipient countries. The composition of migrants to Western Europe by gender, age, level of education, regions of origin, legal status of stay abroad, etc. is analyzed in comparison with Ukrainian migrants to Eastern Europe and the employment population of Ukraine. Special attention is paid to the professional composition of migrants before and after departure. It is concluded that the increase in the share of the European Union in the structure of external labor migration from Ukraine is a positive phenomenon, as it contributes to the spread of European values in Ukrainian society. Future tendencies of Ukrainian migration, in particular in the context of COVID-19 epidemic are estimated. Proposals for improving the migration policy of Ukraine are presented. 
Keywords: migration, labor migration, Ukrainian diaspora, transformation of migration tendencies, migration policy.

Formulation of the problem. In modern conditions, migration is one of the main components of globalization. Borders are becoming more transparent, and their intersection is being simplified, in fact, the world labor market has already formed. More and more people not only live and work outside their countries of origin, but several times during their life change the country of residence. Increasingly, migration is playing the role of a powerful locomotive of world development.

Currently, the UN estimates that the number of people living outside their country of birth exceeds a quarter of a billion [1] - more than $3 \%$ of the world's population. Since the beginning of this millennium, this number has increased almost one and a half times.

Six key population and workforce centers have been formed in the world [2]: 1) North America (USA and Canada); 2) the countries of Western and Northern Europe; 3) Middle East oil-producing countries; 4) countries in the AsiaPacific region; 5) Latin American countries; 6) selected countries of South and Central Africa. Now the second of these centers is expanding to include Southern European countries.

During the 70-90's of the twentieth century in the countries of Southern Europe there have been dramatic changes in the migration situation. The recent history of the region is characterized by the transformation of Italy, Spain, Portugal, and Greece from typical emigration countries into countries that attract migrants from Africa and Latin America, and also their former compatriots and their descendants.

Currently, similar processes are taking place in Eastern Europe. Now Eastern European countries do not represent a large center of attraction for the workforce, although some of them are gradually becoming recipient countries. This is primarily about Poland, where there is now a shift from outflow to influx of population and labor. The return migration of Poles and the influx of foreigners from different countries (especially from Ukraine) are becoming more noticeable. It is worth noting the significant socio-economic and cultural potential of the countries of the Eastern European region. With successful economic development, Eastern European countries have the opportunity to become a new center of attraction for the workforce.

In the presented article, the term "Western Europe" also refers to the countries of Northern and Southern Europe as opposed to Eastern Europe as a set of countries of the former USSR and the Warsaw Pact.

The most common are economic migration, first of all temporary trips in search of higher earnings. Ukraine is one of the largest countries providing labor force in Europe (Western and Eastern). The living standards and living conditions 
of Ukrainian population remain rather low. They are a strong push factor for migration out of Ukraine with purpose of employment.

The purpose of the paper is a comparative analysis of the migration of Ukrainians to different regions of Europe.

Methods of the research - system approach, method of complex use of information from different sources, comparative, graphic methods. It is revealed that the current system of migration statistics in Ukraine can be defined as partially acceptable for the assessment of migration processes in general [3], and labor migration from Ukraine in particular. Special surveys are the way to solve the problem. The assessment of the migration of Ukrainians to the countries of Europe is based on data from three national surveys on external labor migration $(2008,2012,2017)$, a survey in the framework of the TEMPER project with the participation of the author (2017-2018), as well as data from a number of studies of Ukrainian labor migration conducted in Ukraine and in recipient countries.

Analysis of recent research and publications. External labor migration is in the spotlight of Ukrainian scientists. In particular, these issues are considered in the works of E. Libanova, O. Malynovs'ka, I. Prybytkova, M. Romanyuk. In 2020 there was a series of publications devoted to changes migration trends in terms COVID-19 [4; 5]. Scientific novelty of the paper is to identify the features of external labor migration of citizens of Ukraine depending on the geographical direction of movement.

Tendencies of migration from Ukraine. Although most migrants from Ukraine are labor ones, study migration has also become widespread. Since the end of the last century, the number of Ukrainians who study abroad has increased several times (fig. 1). Moreover, the steady growth in the contingent has been observed since 2007. Particularly sharp growth took place in 2012-2016 (more than twice), and only in 2017 this process was suspended. Nowadays, Ukrainian citizens mainly go to study in EU countries, where employment and earnings opportunities are much better than in Ukraine and other CIS countries. The number of Ukrainian students in Poland, where special education programs for Ukrainians have been introduced, has increased especially dramatically. Between 2013 and 2016, there has been more than a threefold increase in the number of Ukrainians receiving education in Polish higher education institutions [6].

Studies show that Ukrainian youth are ready to study abroad even in order to acquire a working profession. That is, any training in other countries, in particular in Poland, is viewed by young Ukrainian people as a kind of social elevator, a direction of increasing social status. Instead, training in vocational schools of Ukraine is considered not prestigious. As a result, even in the face of increased demand for skilled workers in the Ukrainian labor market, only $14 \%$ of schoolchildren plan to receive vocational training. At the same time, $85 \%$ of them are attending higher education. At the same time, $73 \%$ of young people who want to 


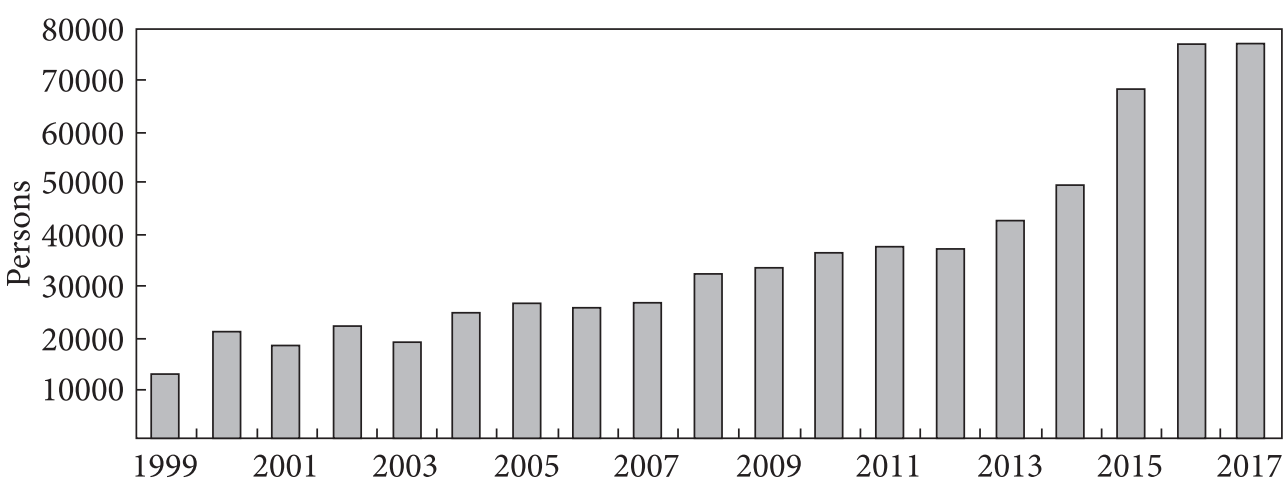

Fig. 1. The dynamics of the number of Ukrainian citizens studying abroad in 1999-2017 Source: UNESCO.

get a higher education would not agree to get a vocational education, even with higher pay and stability [7].

A significant proportion of young people leave Ukraine to study in order to gain access to the EU countries' labor market. This is facilitated, in particular, by the fact that recipient countries typically view graduates in their higher education institutions as one of the most desirable immigrant contingents. EU law allows foreigners to stay in the EU for at least 9 months after completing their studies. This time can be successfully used to find a job. Thus, the likelihood of enrollment of educational migrants in recipient countries increases. According to numerous surveys conducted in Ukraine and recipient countries (in particular in Poland), great majority of Ukrainian educational migrants, both actual and potential ones, do not plan to return after graduating [8].

Labor migration from Ukraine was formed in the mid-1990s. Before this socalled shuttle trade, i.e. travel abroad and back to resell goods, was common among Ukrainians. Shuttle traders were able to establish connections in foreign countries, which they then used to make labor migrations.

Three times nation-wide surveys on labor migration (LMS) were conducted by State Statistics Service of Ukraine (SSSU) in 2008 [9], 2012 [10] and 2017 [11]. However, these surveys could not include the households, where all family

Table 1. Scale of External Labor Migration, million

\begin{tabular}{|l|c|c|c|}
\hline \multicolumn{1}{|c|}{ Source of data } & 2008 & 2012 & 2017 \\
\hline Nationwide survey data & 1.5 & 1.2 & 1.3 \\
Estimation of total size: & & & \\
All migrants & 2.1 & 1.9 & 2.7 \\
Long-term migrants becoming permanent ones & 0.5 & 0.7 & 1.0 \\
\hline
\end{tabular}

Sources: SSSU, author's estimation. 


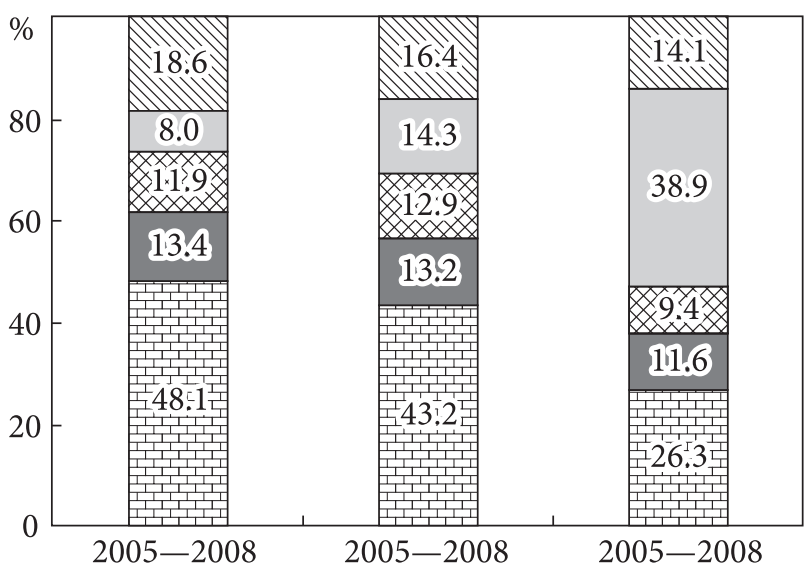

$\mathbb{Q}$ other

$\square$ Poland

Czech Republic

Italy

Russian Federation

Fig. 2. Ukrainian Labor Migrants by Receiving Countries Source: SSSU.

members had migrated and have been living abroad for many years. They did not also include the persons, who went abroad for work before 2005 (LMS-2008), 2010 (LMS-2012) or 2015 (LMS-2017) and have not returned since then. Therefore, the actual number of Ukrainians working abroad is higher and according to estimation reaches 2.7 million persons [8]. About 1 million from them are longterm migrants becoming permanent ones (table 1 ).

According to LMS-2017, the main countries of destination of Ukrainian labor migrants are Poland, Russia, Italy, Czech Republic (fig. 2), the United States, and Belarus. Portugal ranked seventh (1.6 \%) followed by Hungary, Israel, Finland and Germany [11]. Compared with LMS-2012, there was a great decrease in the share of working in Russia with increasing the proportion of workers in the EU, especially in Poland.

As a rule, male dominate among external labor migrants. Noticeable differences are observed in the direction of the external labor migrations of men and women. Thus, regarding the main recipients of the Ukrainian labor force, there is a sharp dominance of women among migrants to Italy. Czech Republic and Russia attract mostly male migration from Ukraine. The education level of labor migrants is much lower as compared with all population in working age. The population of rural areas is more actively involved in labor migration than residents of urban settlements. In the rural areas $6.9 \%$ of population aged $15-70$ are involved in labor migration, whereas in urban settlements - $3.4 \%$.

According to LMS-2017, the share of young people (aged under 35) among migrant workers has decreased from $45.1 \%$ to $41.3 \%$ compared to the previous survey (LMS-2012). Compared to persons over 35 years of age, young people are more oriented to travel to Poland and the Czech Republic and to a much lesser extent to travel to Italy. The share of workers in Russia among young people and people over 35 is almost the same, but compared to LMS-2012, the proportion of young people who go to work in Russia has decreased. 
Russia's popularity among Ukrainians as a country of employment has begun to decline since the beginning of the 21st century. In 2012 compared with 2008, there also was a decrease in the share of working in Russia with increasing the proportion of workers in the EU [10].

Reorientation of Ukrainians working in Russia to EU countries is an objective process. Among the factors that caused the leadership of Russia by the number of Ukrainian labor migrants are the absence of language barrier, visa-free regime, and existence of relatives and friends of Ukrainian migrants in Russia. However, the economic gain of migration to Russian was always lower, than of migration to the countries of the EU. Studies show that migration to Russia has always been less cost-effective than migration to the EU, working conditions of Ukrainians in Russia are considerably worse. Workers in Russia are the most social unprotected and have the lowest level of income among the all Ukrainian labor migrants.

According to LMS-2008 $15.2 \%$ of Ukrainian who worked in Russia had a work, which was different from promised one, $13.0 \%$ had unfavorable working conditions, $13.9 \%$ of Ukrainian faced with non-payment or insufficient payment of salary [9]. These rates are higher than ones in the other main recipient countries. By the time of LMS-2012, the difference between working conditions for Ukrainians in Russia and in the other destination countries even increased. In 2012 the average earnings of Ukrainian labor migrants in Russia was twice less than in Germany and at 7-23\% lower than in the Czech Republic, Portugal, Italy, Hungary and Spain [10].

According to LMS-2017, $26.6 \%$ of Ukrainians who worked in Russia and had an employment contract with their employers did not qualify for any social benefits - the highest rate among the contingent of migrants who had an employment contract in four major recipient countries. Only in $12.2 \%$ of cases the right to social insurance was enshrined in the employment contract (in Belarus $14.2 \%$, in other recipient countries - $16.3-58.8 \%$ ), only in $8.5 \%$ of cases the right to health insurance (in other recipient countries $-18.1-72.5 \%$ ).

The average working week for Ukrainians in Russia was, according to LMS2017, 52.5 hours (more than in any other of the 11 major recipient countries). $10.9 \%$ of employees were faced with the fact that their actual work was different from what was promised, $6.1 \%$ - with transfer from one employer to another, $13.4 \%$ - with forced labor in unfavorable conditions, $29.3 \%$ - with delays or incomplete payment of wages, $5.9 \%$ - with forced overtime unpaid work [11]. All these indicators are much higher than their counterparts in other countries [8].

The differences between the working conditions of Ukrainians in Russia and in other recipient countries are steadily increasing. Particularly sharply (more than twice in 9 years) the share of Ukrainian wage earners with delayed or incomplete wages, the share of unpaid overtime workers and those who worked in adverse conditions increased in Russia. In general, according to LMS-2017, 56.2 \% 
of workers in Russia and $66.5 \%$ of all migrant workers from Ukraine found their working conditions normal [11]. The average earnings of Ukrainian labor migrants in Russia in 2017 was 2-3 times lower than in USA and Israel, and at 19-42\% lower than in the Czech Republic, Portugal, Italy and Germany.

Dramatic events that have been taking place in Ukraine since 2014 make an impact on all aspects of social development. Among others, Ukraine's migration situation has been changing permanently. Particularly process of reorientation of Ukrainian labor workers to the countries of the EU will increase in conditions of deterioration of Ukrainian-Russian relations.

There are other factors that contribute to re-orientation:

- campaigns of legalization of migrants that are conducted periodically in the countries of the EU;

- fall in exchange of Russian ruble to Euro and currency of the countries which are the new EU members;

- forming of migration networks and public organizations of Ukrainians in the EU countries;

- visa-free regime for Ukrainians to the countries of Schengen zone granted to Ukraine in June 2017.

The visa-free regime does not ensure Ukrainian citizens with opportunities of non-restricted access to the EU. Those persons, who wish to enter the European Union, still need to provide some documents for justifying the purpose of their visit, their financial security, etc. In contrast to the previous practice, these documents are reviewed not by consulate employees, but by border guards. However, due to the visa-free regime with the EU, the opportunities for international mobility of Ukrainians have greatly expanded, and foreign travel has become easier and cheaper. Potential migrants to EU countries can legally stay in European countries for 3 consecutive months, during this time they can try to find a job, evaluate the employment opportunities and conditions in general of stay "on site" and make a more informed migration decision.

Ukrainian migration to Western and Eastern Europe. A comparative analysis of the migration of Ukrainians to Western and Eastern Europe shows that the main differences are: in Western Europe, the proportion of female is higher; migrants to "old" EU are more likely to have legal status; they are less likely to work in accordance with their qualifications and are more often employed in elementary occupations (table 2). However, they have more earnings and better working conditions, since the level of salaries in Western Europe is higher than in Eastern Europe.

According to LMS-2008 and LMS-2012, residents of Western Ukraine worked mainly in Eastern European members of the EU and, to a lesser extent, in Western Europe and Russia. At the same time, labor migrants from the other four economic zones of Ukraine (North, Center, South and East) went mainly to Russia and partly to Western European countries. At present, the differences be- 
tween the regions of Ukraine in the directions of migration are gradually being leveled. According to LMS-2017, Poland ranks first among destination countries for not only migrants from Western, but also from Northern, Central and Southern Ukraine. Migration to Russia is still predominant in the East alone [11]. According to the National Bank of Poland, the share of immigrants from the South and East of Ukraine in the structure of Ukrainian migration to Poland increased from $6.3 \%$ to $28.4 \%$ after the beginning of the 2014 conflict [12]. In 2017, compared to 2012, the proportion of immigrants from the Western economic zone among Ukrainians working in Italy and Portugal decreased.

Nevertheless, the main difference is the duration of migrations to two regions of continent. As a whole, migrants to neighboring countries (Russia, Poland, Czech Republic, Hungary) as a usual make periodic short trips with a permanent return to Ukraine, i.e. they are engaged in circular migration. Migrants to Mediterranean countries usually stay on working there for a longer period of time (fig. 3). Migration to Western Europe is characterized by a transition from circular to permanent migration (as such cases were rare in the 1990's), with the formation of new Ukrainian Diasporas in the recipient countries. In particular, the long-term migrants, who have become accustomed in Western Europe, increasingly bring their families to the recipient countries. In the present conditions, these trends intensify due to a deterioration of economic and political situation in Ukraine. It must be fully understood that some labor immigrants will not return to Ukraine at all.

Example of Spain demonstrates this trend. According to the survey-2012, Spain ranked fifth in the ranking of recipient countries [10]. However, in 2017 the migration to Spain was lower than the threshold value for which country data was published. This is unlikely to be a consequence of the decline in migration to Spain and probably this reflects the transition of long-term labor migrants to

Table 2. Selected indicators of external labor migration from Ukraine to Western and Eastern Europe, 2017 ( \%)

\begin{tabular}{|c|c|c|c|}
\hline Indicator & $\begin{array}{l}\text { Western } \\
\text { Europe }^{1}\end{array}$ & $\begin{array}{l}\text { Eastern European } \\
\text { EU members }{ }^{2}\end{array}$ & $\mathrm{CIS}^{3}$ \\
\hline Proportion of female & 57.9 & 29.7 & 16.7 \\
\hline Proportion of migrants without official status & 8.9 & 14.4 & 31.5 \\
\hline $\begin{array}{l}\text { Proportion of migrants who worked abroad } \\
\text { according to the obtained qualification }\end{array}$ & 13.4 & 20.8 & 38.3 \\
\hline $\begin{array}{l}\text { Proportion of migrant workers in elementary } \\
\text { occupations }\end{array}$ & 56.0 & 48.1 & 28.3 \\
\hline
\end{tabular}

${ }^{1}$ Data includes Italy, Portugal, Finland and Germany; ${ }^{2}$ Data includes Poland, Czech Republic and Hungary; ${ }^{3}$ Data includes Russian Federation and Belarus.

Source: SSSU. 


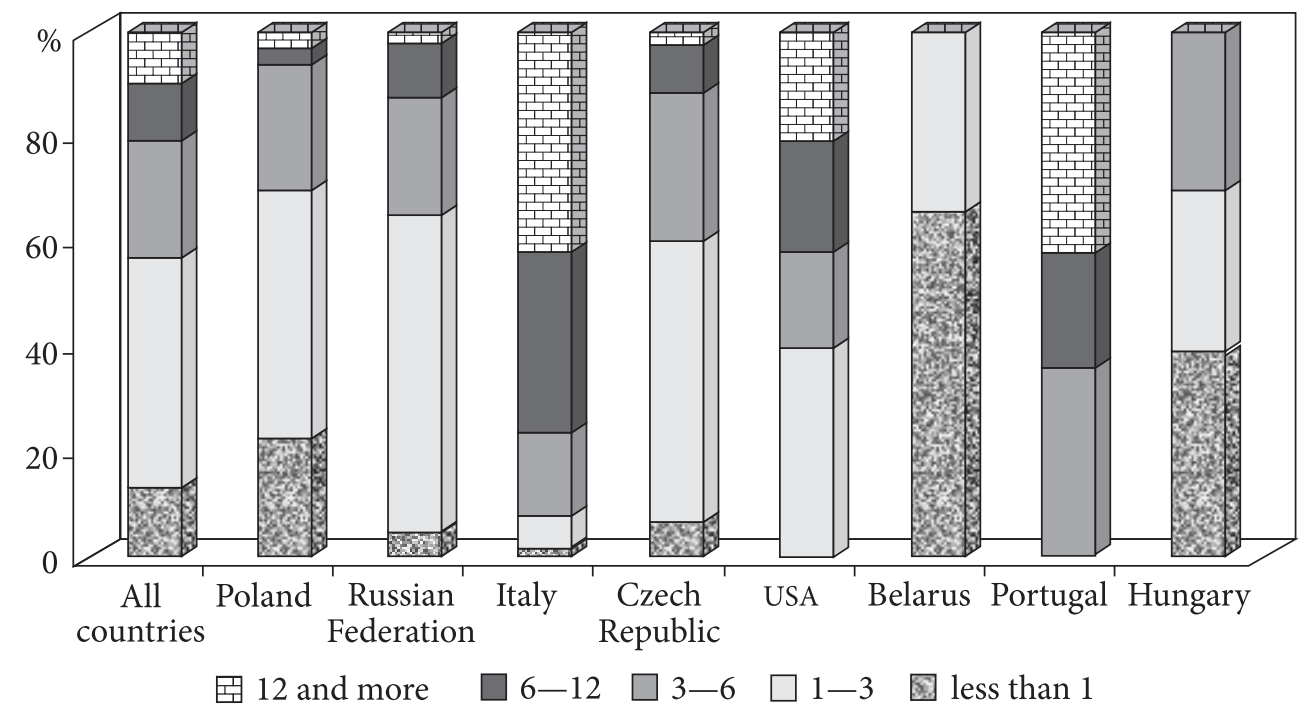

Fig. 3. Labor migrants by countries of migration and duration of stay during last trip, 2015-2017, months

Source: SSSU.

the permanent ones. The proportion of long-term migrants in Spain in 2012 was much higher than in other recipient countries (fig. 4).

According to a survey of Ukrainian migrants in Paris conducted at the end of 2017, 3 years is the threshold that determines migrants' plans. Having been in France for up to 3 years, respondents are still expecting to return to Ukraine, that is, they perceive their own stay in France as temporary. However, if they have been in France for more than 3 years, their plans change, and now this country is not a temporary stage in migration but a new place of permanent residence [13].

According to survey of Ukrainian return migrants conducted in the framework of the TEMPER project (2017-2018), almost all of them have confirmed that they feel at home in Ukraine (97\%). At the same time about a quarter of returners have the same feeling in the last country of destination. Returners from Italy have reported that they feel there at home more often than returners from Poland (28\% vs $24 \%$ ) [14]. This also shows the difference in the nature of migration to Western and Eastern Europe. Unfortunately, TEMPER survey covered return migrants from two countries only. There is a relationship between feeling of belonging to the destination country and time that migrants spent abroad. Almost half of returners who stayed in Europe over 5 years have reported about these feelings. And only one of five among migrants who stayed abroad less than two years has confirmed the same belonging. Among migrants who stayed abroad from two to five years about $40 \%$ feel at home in the last country of destination.

While staying abroad the majority of Ukrainian migrants work on low-skilled positions and almost all others do skilled manual work. Migrants who worked in 


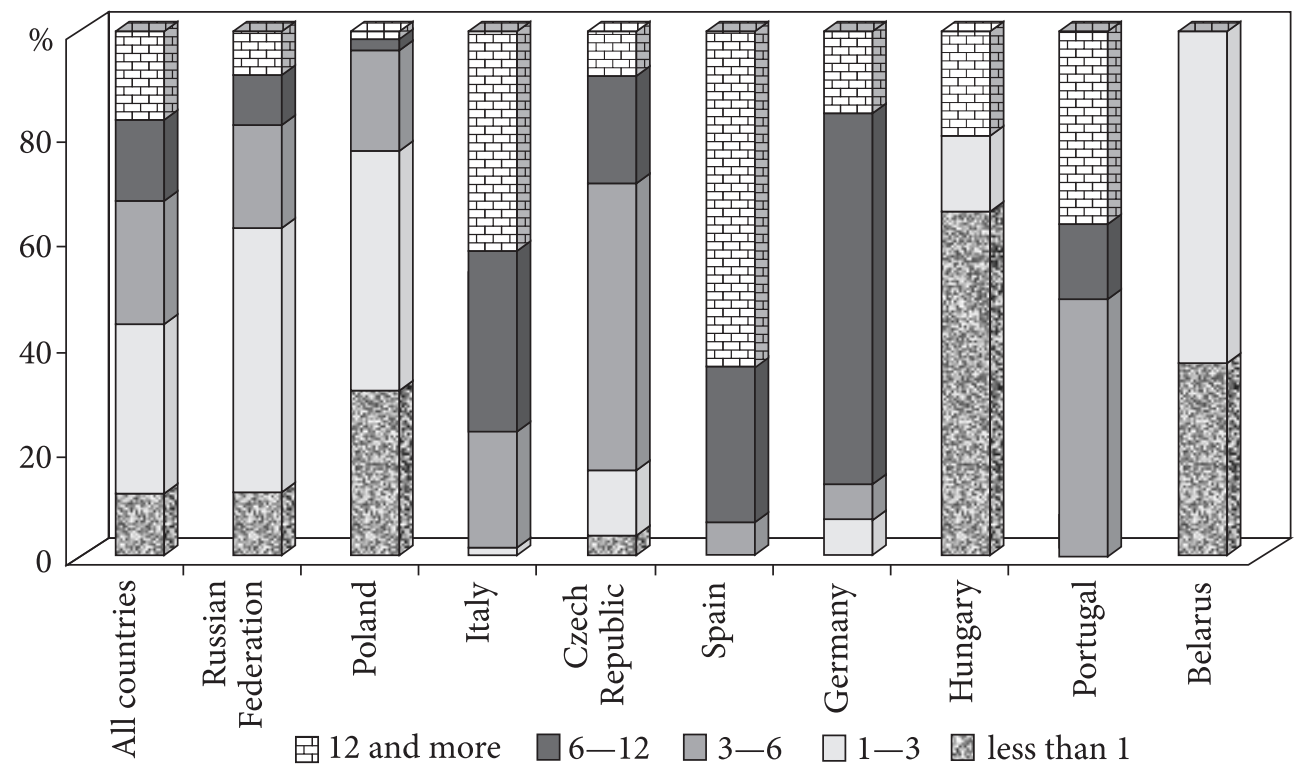

Fig. 4. Labor migrants by countries of migration and duration of stay during last trip, 2010-2012, months

Source: SSSU.

Italy were employed by low-skilled jobs much more often than migrants who worked in Poland - $75 \%$ against $59 \%$ in their first job abroad and $75 \%$ against $56 \%$ - in their last work before return. People with a high education performed low-skilled jobs abroad more often than less educated persons [15]. Thus, one of the consequences of external labor migration is the decline of the qualifications of Ukrainian workers.

Only slightly more than a quarter of Ukrainian migrants have had work abroad in accordance with skills obtained in Ukraine [11]. At the same time, over a third of the migrants worked on jobs that did not require qualifications. Herewith representatives of the working occupations usually retain or even improve their qualification status, while representatives of the occupations, which are mainly related to mental work, are forced to do less skilled jobs (table 3).

Compared to the population employed in the domestic labor market, the share of professionals, technicians, associate professionals and clerical support workers is more than 3.5 times lower among migrant workers. Instead, the share of skilled workers and representatives of the elementary occupations among migrants is $2.1-2.2$ times higher. Such differences in the structure of labor migrants and the occupied population of Ukraine by occupational groups are further evidence of the overwhelming employment of migrants in not prestigious jobs [8].

Breakdown of migrants by activity type varies substantially depending on gender and the country of stay. In particular, Ukrainian male labor emigrants 
were mainly engaged in construction. That economic activity type dominates among the men working in Portugal, Czech Republic, the Russian Federation and Hungary.

For male Ukrainians working in Belarus, construction is one of the two basic activity areas along with agriculture; a high share of persons employed in agriculture is also recorded among those migrating to Poland and Finland. Among the Ukrainian men working in Poland, there is a high percentage of those employed in industry and trade; in Italy - in industry and household activities; in Hungary - in trade, in Germany - in transport.

The employment structure of female Ukrainian migrants varies considerably depending on the country of stay. Key activities include working in households (from the four major recipient countries it is especially common in Italy and Russia), agriculture (in Poland), industry (in Czech Republic and Poland), trade (mainly in the Russian Federation and Poland) and hotels and restaurants (mainly in Czech Republic).

Recently, there has been an increase in migration of Ukrainians to Eastern European countries (especially to Poland). Respectively, the share of Western European countries has decreased. However, in the future, an increase in flows to Western Europe, in particular to Germany, is expected. Germany opened labor

Table 3. Labor migrants by occupation groups abroad depending on the last occupation before migration, 2015-2017 ( \%)

\begin{tabular}{|c|c|c|c|c|c|c|c|}
\hline \multirow[b]{2}{*}{ Last occupation before migration } & \multicolumn{7}{|c|}{ Occupation groups abroad } \\
\hline & 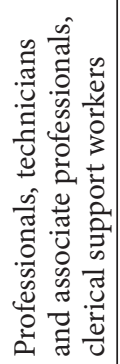 & 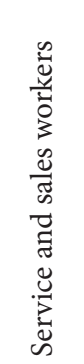 & 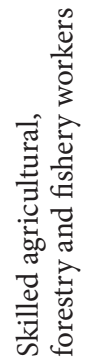 & 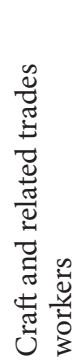 & 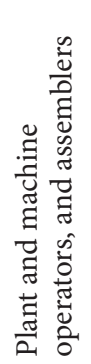 & 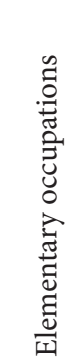 & $\stackrel{\text { चै }}{0}$ \\
\hline $\begin{array}{l}\text { Professionals, technicians and associate } \\
\text { professionals, clerical support workers }\end{array}$ & 29.2 & 12.8 & 0.0 & 21.3 & 3.0 & 33.7 & 100.0 \\
\hline Service and sales workers & 4.0 & 25.4 & 0.0 & 8.6 & 3.8 & 58.2 & 100.0 \\
\hline $\begin{array}{l}\text { Skilled agricultural, forestry } \\
\text { and fishery workers }\end{array}$ & 0.0 & 22.8 & 20.2 & 43.9 & 0.0 & 13.1 & 100.0 \\
\hline Craft and related trades workers & 0.1 & 6.5 & 1.6 & 66.0 & 0.9 & 24.9 & 100.0 \\
\hline $\begin{array}{l}\text { Plant and machine operators, } \\
\text { and assemblers }\end{array}$ & 8.6 & 1.6 & 0.0 & 21.6 & 51.4 & 16.8 & 100.0 \\
\hline Elementary occupations & 1.4 & 8.3 & 4.5 & 17.6 & 2.0 & 66.2 & 100.0 \\
\hline
\end{tabular}

Source: State Statistics Service of Ukraine. 
Ukrainian migrants in Europe: situation depending on the region of stay

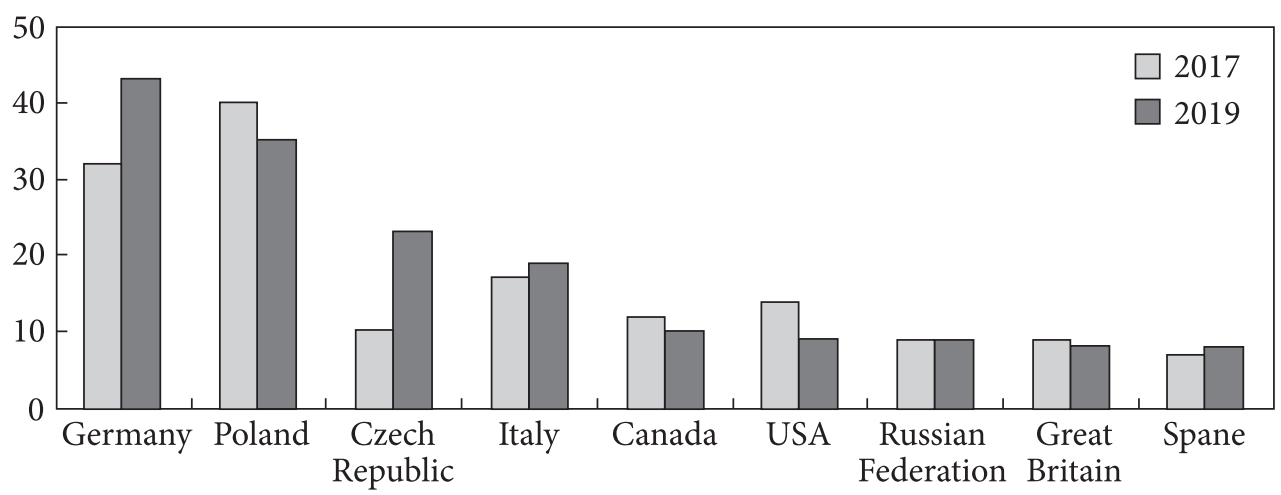

Fig. 5. Desired countries for working abroad (among respondents considering working abroad; respondents could select multiple answers)

Source: IOM Mission in Ukraine.

market for migrants from outside the EU since beginning of 2020. According to survey on migration and human trafficking conducted by the International Organization for Migration Mission in Ukraine in June-August 2019, Germany has become the most desirable country of employment for Ukrainian migrants [16]. According to similar survey conducted in 2017, Poland was the most desirable country [17] (fig. 5).

New employment scheme for Ukrainians in Germany has already emerged. Ukrainian worker receives work permit in Poland. It is not difficult. Then Polish company sends him or her on a "business trip" to Germany. Therefore, it is believed that he works in Poland, but in fact, he works in Germany.

The possible reorientation of part of the Ukrainian migrants from Poland to Germany is facilitated not only by the difference in the level of earnings between the two countries, but also by the deterioration of the attitude of part of the Polish population to Ukrainians and the policy of the Polish Government on the "Ukrainian issue".

A dilemma arises now. The government of Poland tries to attract labor migrants from Ukraine. At the same time, investigation of the complicated Ukraine-Poland history by the Polish leadership and its unilateral interpretation do not promote the development of good-neighborliness between two countries. Now the attitude of Poles towards Ukrainians is generally positive. But in the future, the policy of the Polish Government may result in the spread of cases of negative attitudes towards Ukrainians among some Poles and, as a consequence, in a reduction in the flow of labor migrations from Ukraine to Poland and the outflow of Ukrainian migrants from Poland to the wealthier countries of Western Europe. Several years ago, the Russian Federation was interested in the Ukrainian labor migrants, and now Russia is also interested in them, but the current policy of the Russian leadership towards Ukraine contributes to a reduction of labor migration from Ukraine. 
Consequences of migration and possible future. Labor migration has both positive and negative aspects. It leads to an increase in the welfare of certain segments of the population. In terms of the ratio of private money transfers to GDP, Ukraine is at the level of Serbia, Montenegro, and Albania, slightly behind Georgia, Armenia, and Bosnia and Herzegovina [18]. Money remittances are important source of well-being of migrants' families, but mostly costs are spent on consumption. Unfortunately, efficiency of mobilizing these funds into the regional economy leaves much to be desired. The engagement of former labor migrants into business activities is extremely low which is caused by insufficiently favorable conditions for launching private business in Ukraine. The quantity of migrants and their relatives who start their own business in Ukraine could be more.

Money remittances are directed mainly to western regions, where wage levels are lower. Calculations show that transfers from migrants workers negate sixth of the existing differences in incomes of the population among regions of Ukraine [19]. Labor migration also reduces labor market tension. In case of absence of external labor migration from Ukraine, the unemployment rate in the country in certain years would be 1.5-2 times higher than the actual indicators [8]. In addition, a long stay of the individual in the European countries means the incorporation of the market consciousness, values and norms of a civilized society.

At the same time, there are acute negative effects of the large-scale outflow of labor force that the Ukrainian labor market is experiencing. A lack of appropriate workforce is an obstacle to the creation of new jobs, and in the future, the situation will inevitably worsen. Ukrainian citizens often engage in unskilled jobs and lose their qualifications accordingly. Since most migrants are married, work trips pose risks for marital relations and socialization of children. Another problem is related to the threat of diminishing social significance of employment in Ukraine: a stable stereotype is formed in the youth of certain regions, according to which achievement of decent living standards is possible only through working trips abroad.

Anxiety is caused not so much by the migration losses as by the departure of skilled workers. Negative trends in the economy of Ukraine and in the labor market in 2014-2015 have led to the fact that young people, as well as educated and highly qualified specialists, have become increasingly involved in labor migration [20]. As a result, even in the presence of a contingent of unemployed, there is a shortage of workers who meet the requirements of employers in terms of their qualifications. By the end of 2017, almost half of Ukrainian companies have already had trouble in recruiting staff due to labor migration abroad. More than a quarter of companies are forecasting appropriate risks in the near future.

The COVID-19 epidemic is adjusting labor migration trends. Quarantine is introduced in EU countries, interstate transport is almost closed. Partial restoration of border control and partial closure of borders within the Schengen area have occurred. Entire sectors of the economy are frozen, and many enterprises 
where migrants from Ukraine have worked have suspended their activities. This situation led to the massive return of Ukrainians to their homeland [5]. Circular migrants usually return and stop traveling, while permanent residents of the recipient countries tend to stay abroad. Some migrants try to find employment in industries that continue to operate - selling food or delivering goods [21].

The ability to resume external labor migration of Ukrainians will depend on the pace of economic recovery in EU countries. Obviously, there will be a change in the structure of Ukrainian migration by type of activity. The proportion of those areas where labor demand is unlikely to fall - trade, household activity and, in particular, agriculture - will increase. Some European states organize pilot scheme for inviting Ukrainian citizens to seasonal farm work, as well as facilitating charter transportation for workers.

Conclusions. The problem of the outflow of population is very important for Ukraine. The number of external labor migrants from Ukraine exceeds 2 million.

In the history of labor migration from Ukraine, there has been a radical reorientation of migration flows from Russia to EU countries, mainly to Poland and other Eastern European countries. There is now a new reorientation of migrants from Eastern to Western Europe, most notably Germany and probably the United Kingdom. After Brexit, Ukrainian citizens receive almost the same job opportunities in the UK as citizens of the enlarged EU. It is precisely in crises, similar to the current period of the COVID-19 epidemic, the natural tendencies, which have previously developed at a slow pace, tend to intensify. For example, the reorientation of migrants from Russia to the EU countries, which gradually took place over a decade and a half, increased sharply in the context of the beginning of the military conflict in eastern Ukraine.

The increase in the share of the European Union in the structure of external labor migration from Ukraine is a positive phenomenon, as it contributes to the spread of European values in Ukrainian society.

The main task of the state migration policy is to ensure effective use of the migration results for development while minimizing its negative effects. Ukrainian Government cannot stop migration of Ukrainians to European Union. Strategic objective ought to be gradual return of those labor migrants who are ready or under certain circumstances can be ready for re-emigration. It is time to take measures to improve the business climate in Ukraine. Entrepreneurship support programs should be implemented as soon as the epidemic is over. This may keep the part of persons who have returned to Ukraine in March 2020, from further migration. Given the impossibility of prohibiting departure, it is important not to lose these people to Ukraine and to maximize the benefits of cooperation with the Diaspora. This will help to improve the situation in the economy and strengthen Ukraine's position in the world.

It is important for Ukraine to start negotiations with the governments of recipient countries for the purpose of the development and implementation of 
programs of circular migration: it is beneficial not only for Ukraine, but also for the recipient countries. It means that Ukraine has real opportunities to negotiate with the EU on the involvement of relevant countries in financing these programs.

The further the greater the scale of international migration is likely to increase. The Fourth Industrial Revolution and digitalization of the economy, the development of transnational corporations, the deployment of a large part of the production outside the head office, and the further simplification (cancellation) of border crossing procedures will facilitate this. An important factor in increasing the intensity of migration is the growing need for economically developed countries in the workforce due to the aging of their population. The proportion of older people increases resulting in a deterioration of the ratio between the output of material goods and services, on the one hand, and recipients of pensions and social benefits the other side. Thus, migration does act as factor of demographic security. All over the world, migrants fill niches that are not in demand in the local population. Migrants do not compete with the local population in the labor market. Migrants compete only with other migrants, for instance Ukrainian and Brazilians in Portugal.

European Union needs migrants and European Union will need much more migrants. As the epidemic fades, restrictions on population movements are likely to be lifted. Two ways allow the use migration opportunities and avoid threats. The first option is the resettlement of migrants in the country with ensuring their integration. A more favorable option for the host countries is to ensure the return of migrants. In this case, the interests of the recipient countries and donor countries are facing.

The European Union should cooperate with Ukraine, as well as with Moldova, Georgia, countries of Asia and Africa to support a temporary circular migration as an alternative to permanent migration.

\section{REFERENCES}

1. International Migration Report 2017. (2017). Retrieved from http://www.un.org/en/ development/desa/population/migration/publications/migrationreport/docs/Migration Report2017_Highlights.pdf

2. Savitska, O., \& Chonyo, V. (2013). Osoblyvosti mihratsinykh protsesiv naselennia v umovakh hlobalizatsii [Features of migration processes of the population in the conditions of globalization]. Scientific Bulletin of National Forestry University of Ukraine, 23.17, 295-303. [in Ukrainian].

3. An Assessment of the Collection, Distribution, Storage and Analysis of Migration Information in Ukraine. (2015). Kyiv : IOM, Mission in Ukraine.

4. Minich, R., \& Kravchuk, P. (2020). The Impact of COVID-19 on Ukrainian Labour Migrants in Czechia, Hungary, Poland and Italy. Policy Brief. Retrieved from https://www. pragueprocess.eu/documents/repo/212/Policy_Brief_Minich_Kravchuk_EN.pdf

5. Libanova, E. M., \& Pozniak, O. V. (2020). Zovnishnia trudova mihratsiia $z$ Ukrainy: vplyv COVID-19 [External labor migration from Ukraine: the impact of COVID-19]. Demo- 
graphy and Social Economy, 4 (42), 25-40. https://doi.org/10.15407/dse2020.04.025 [in Ukrainian].

6. United Nations Educational, Scientific and Cultural Organization. (2020). Retrieved from http://data.uis.unesco.org

7. Libanova, E., Tsymbal, O., Yarosh, O., \& Lisogor, L. (2016). The transition of Ukrainian youth to the labor market: results of an international study "School-to-work transition surveys» in Ukraine in 2013 and 2015. Geneva : ILO.

8. Ukrainske suspilstvo: mihratsiinyi vymir : nats. dopovid [Ukrainian society: the migration dimension. National report] (2018). Institute of Demography and Social Studies of NAS of Ukraine. Kyiv [in Ukrainian].

9. Zovnishnia trudova mihratsiia naselennia Ukrainy [Ukrainian External Labor Migration]. (2009). Ukrainian Center for Social Reforms. Kyiv [in Ukrainian].

10. Report on the Methodology, Organization and Results of a Modular Sample Survey on Labor Migration in Ukraine. (2013). International Labor Organization. Budapest.

11. Zovnishnia trudova mihratsiia naselennia (za rezultatamy modulnoho vybirkovoho opytuvannia). Statystychnyi biuleten [External labor migration of the population (according to the results of the modular choice of the survey). Statistical bulletin]. (2017). State Statistics Service of Ukraine. Kyiv [in Ukrainian].

12. Chmielewska, I., Dobroczek, G., \& Puzynkiewicz, J. (2016). Citizens of Ukraine working in Poland - survey report. National Bank of Poland. Warszawa [in Polish].

13. Mikheyeva, O. (Eds). (2018). Vyklyky suchasnoi mihratsii: ukrainska spilnota v Paryzhi [Challenges of Contemporary Migration]: The Ukrainian Community in Paris. Lviv : The Ukrainian Catholic University [in Ukrainian].

14. Lenoël, A., Cerrutti, M., Croitoru, A., Hnatyuk, T., Maguid, A., Maidanik, I. et al. \& Vandenbunder, A. (2018). Report on Non-Economic Impacts of Temporary, Circular and Permanent Migration. TEMPER EU Project. Retrieved from http://www.temperproject.eu/ wp-content/uploads/2019/12/Working-Paper-12-TEMPER.pdf

15. Obućina O., Beauchemin C., Cerrutti, M., Deliu, A., Havryliuk, O., Lenoël, A. et al. \& Vandenbunder, A. (2018). Report on the Economic Integration of Return Migrants. TEMPER EU Project. Retrieved from http://www.temperproject.eu/wp-content/uploads/2019/12/ Working-Paper-11-TEMPER.pdf

16. International Organization for Migration. (IOM). (2019). Survey on migration and human trafficking in Ukraine, Moldova, Belarus and Georgia, 2019. Retrieved from http://iom.org. ua/sites/default/files/iom_regional_ct_survey_2019_eng_print.pdf

17. International Organization for Migration. (IOM). (2017). Survey on migration and human trafficking in Ukraine, 2017. Retrieved from http://iom.org.ua/sites/default/files/migration_ and_human_trafficking_in_ukraine_eng.pdf

18. Pererakhunok danykh pro pryvatni hroshovi perekazy v Ukrainu za 2015-2017 roky [Recalculation of data on private money transfers to Ukraine for 2015-2017] (2018). National Bank of Ukraine. Kyiv. Retrieved from https://bank.gov.ua/admin_uploads/article/ Remittances \%20_2015-2017.pdf? $v=4$ [in Ukrainian].

19. Pozniak, O. (2016). Otsiniuvannia naslidkiv zovnishnoi trudovoi mihratsii v Ukraini [Evaluation of consequences of external labor migration in Ukraine]. Demography and social economy, 2 (27), 169-182. https://doi.org/10.15407/dse2016.02.169 [in Ukrainian].

20. Drbohlav, D., \& Jaroszewich, M. (Eds.) (2016). Ukrainian Migration in Time of Crisis: Forced and Labor Mobility. Prague.

21. Ukrainian workers in Poland "migrate" to trade and logistics. Radio Freedom. Retrieved from https://www.radiosvoboda.org/a/30514765.html

Стаття надійшла до редакції журналу 10.03.2021. 
О. В. ПОЗНЯК, канд. екон. наук, зав. сектору

Інститут демографії та соціальних досліджень імені М. В. Птухи НАН України

01032, Україна, Київ, бул. Т. Шевченка, 60

e-mail: olex_poznyak@ukr.net

ORCID 0000-0002-1323-3896

Scopus ID 57195780028; 57189273845

\section{УКРАЇНСЬКІ МІГРАНТИ В ЄВРОПІ: СИТУАЦІЯ В ЗАЛЕЖНОСТІ ВІД РЕГІОНУ ПЕРЕБУВАННЯ}

Україна $є$ одним з найбільших донорів населення та робочої сили в Європі. Оцінювання міграції українців до країн Європи базується на даних трьох загальнонаціональних опитувань щодо зовнішньої трудової міграції $(2008,2012,2017)$, опитування в рамках проєкту TEMPER за участю автора (2017-2018), а також даних низки інших досліджень української трудової міграції, проведених в Україні та країнах-реципієнтах. Метою статті $\epsilon$ порівняльний аналіз міграції українців до різних регіонів Європи. Методи дослідження: системний підхід, метод комплексного використання інформації 3 різних джерел, порівняльний та графічний методи. Науковою новизною статті $€$ виявлення особливостей зовнішньої трудової міграції громадян України залежно від географічного напрямку переміщень. Проаналізовано зміни в тенденціях зовнішньої трудової міграції українців, що відбулися за часів незалежності. Проведено порівняльний аналіз міграції українців до Західної та Східної Європи. Показано, що трудові поїздки до сусідніх з Україною країн здебільшого залишаються циркулярними та короткочасними. Міграція до Західної Європи характеризується переходом від циркулярної до постійної міграції з формуванням нових українських діаспор у країнах-реципієнтах. Проаналізовано склад мігрантів до Західної Європи за статтю, віком, рівнем освіти, регіонами походження, правовим статусом перебування за кордоном тощо у порівнянні з українськими мігрантами до Східної Європи та зайнятим населенням України. Особливу увагу приділено професійному складу мігрантів до та після виїзду. Зроблено висновок, що збільшення частки Європейського Союзу в структурі зовнішньої трудової міграції з України є позитивним явищем, оскільки сприяє поширенню європейських цінностей в українському суспільстві. Оцінюються майбутні тенденції української міграції, зокрема в контексті епідемії COVID-19. Представлені пропозиції щодо удосконалення міграційної політики України.

Ключові слова: міграція, трудова міграція, українська діаспора, трансформація міграційних тенденцій, міграційна політика. 